\title{
Hardy on Polanowska-Sygulska on Hardy on Berlin on Pluralism and Religion
}

"The history of philosophy is to a great extent that of a certain clash of human temperaments". These are William James's words in the first of his lectures on pragmatism, delivered in $1906^{2}$. Many others have made similar observations.

When I read Professor Beata Polanowska-Sygulska's review of my book about working with Isaiah Berlin and challenging his ideas 3 , it seemed to me to exemplify the truth enunciated by James. Polanowska-Sygulska is by nature or upbringing, or both, a religious believer, and I am an anticlerical infidel, rebelling against the religious indoctrination of his youth. We bring these pre-existing conditions to the main issue that divides us - the tenability of religious belief by a pluralist - and they, as much as, if not more than, the arguments we deploy, determine the positions we adopt. The fact that she is a Polish cradle Catholic and I a lapsed English Anglican may also be relevant to this bifurcation. Nevertheless, we are good friends (to declare an interest), and share a consuming interest in Berlin's ideas.

The editors of this journal have invited me to respond to Polanowska-Sygulska. Given what I have said above, it may be thought that such a response can amount only to a restatement of the prejudice that I bring to the discussion. But I hope that, having recognised this risk, I am better placed to avoid it. And naturally I do believe that, if we restrict ourselves to the arguments, the case I make can be successfully defended against Polanowska-Sygulska's attempt (and Berlin's) to resist it. I shall indicate briefly here why I say this, leaving a longer rebuttal for another (possibly non-existent) occasion.

The first two parts of the three-part review are gratifyingly positive, as are some passages in the third part, and I shall say nothing about these. As Berlin often observed, disagreement is more interesting and revealing than agreement, since it can reveal weaknesses in the position under attack, and may help to eliminate them. It is in the closing paragraphs of the third part that Polanowska-Sygulska's gloves come off. She begins this part, mistakenly in my view, by raising some minor quibbles rather than plunging straight into the main topic. This distracts the reader from the more important 
matters that follow, especially as what she says is largely irrelevant to them, and mostly unpersuasive. Let me despatch these trivia as briefly as I can:

1. Polanowska-Sygulska wishes to define Berlin's "basic freedom" - his name for free will - as the ability to make choices, rather than as the actual making of choices (the exercise of freedom). This is a distinction without an important difference, for if we did not exercise free will, the mere possession of it would be of no use to us. But in any case, I myself write (she quotes the passage): "freedom of the will (...) enables us to make (...) choices", which is her own and Berlin's position. There is no disagreement here.

2. She objects to my inclusion of "(rational) self-government" in a list of human goals. This is indeed an error on my part, but not the one she supposes. On p. 4 of Liberty Berlin writes of the "social and political ends sought by men - such as unity, harmony, peace, rational self-direction, justice, self-government" 4 . I mistakenly telescoped the last three items as "rational self-government", but this is vanishingly close, if not identical, to rational self-direction, so the error is venial, though I do correct it in the paperback, thanks to Polanowska-Sygulska's query. My parentheses merely indicate that Berlin also wrote of "self-direction" tout court: indeed, that is a synonym for positive liberty. Polanowska-Sygulska's problem is with "rational", but, as we see, it is Berlin's own word, and moreover need not have the Rawlsian overtones she deprecates on Berlin's behalf. As Berlin writes in a letter to which she herself alludes, "I do not look upon rational approaches as fundamentally flawed - what reason can do, it should do"5.

3. I am said not to give enough weight to conflict within values. I explicitly mention this conflict ${ }^{6}$, in what is in any case intended as a short summary of Berlin's views.

4. Polanowska-Sygulska complains that neither I nor Berlin recognise a sense of "cultural pluralism" deployed by Horace Kallen, who uses it to mean multiculturalism. I make perfectly clear what I mean by "cultural pluralism", and am not concerned with other strands in the history of the term, though I do distinguish between cultural pluralism (in my sense) and multiculturalism ${ }^{7}$. Berlin, however, does sometimes use the term in Kallen's sense ${ }^{8}$. This is a tiny red herring.

5. Polanowska-Sygulska queries my remark that moral empiricists may wish to defend their religious beliefs to the death, on the grounds that moral empiricists would not be disposed to hold religious beliefs. I define moral empiricism as the belief that morality is contingent and thus subject to empirical change, by contrast with moral absolutism, which holds that moral truth is a priori and the same in all possible worlds. Polanowska-Sygulska rightly observes that the main religions contain metaphysical theses which are not empirically knowable (for me, another argument against them). But there is no reason in principle (much as I should deplore it in practice) why moral empiricists should not also subscribe to metaphysical religious theses, which, for them, do not include the edicts of morality.

I. Berlin, Liberty, H. Hardy (ed.), Oxford 2002, p. 4.

Unpublished letter to Claude Galipeau, 16 May 1991. Oxford, Bodleian Library, MS. Berlin 227, fols 109-110 at fol. 109v.

H. Hardy, In Search..., p. 175.

H. Hardy, In Search..., p. 205.

For example in another letter to Claude Galipeau, 15 April 1991. In: I. Berlin, Affirming: Letters 1975-1997, H. Hardy, M. Pottle (eds.), London 2015, p. 415. 
6. I criticise Berlin's notion of the common moral core as not allowing for moral progress, and Polanowska-Sygulska counters that Berlin didn't believe in moral progress. But he did. Moral progress is neither inevitable nor irreversible, but it does sometimes occur, as he clearly recognised in, for example, $A$ Message to the Twenty-First Century, a 1994 address in which he speaks of the state of politics at the time:

Rationality, tolerance, rare enough in human history, are not despised. Liberal democracy, despite everything, despite the greatest modern scourge of fanatical, fundamentalist nationalism, is spreading. Great tyrannies are in ruins, or will be - even in China the day is not too distant. I am glad that you to whom I speak will see the twenty-first century, which I feel sure can be only a better time for mankind than my terrible century has been. I congratulate you on your good fortune; I regret that I shall not see this brighter future, which I am convinced is coming. With all the gloom that I have been spreading, I am glad to end on an optimistic note. There really are good reasons to think that it is justified ${ }^{9}$.

7. Finally, Polanowska-Sygulska takes me to task for writing: "pluralism means that ultimate ends necessarily conflict". As she rightly observes, "They may conflict but they need not". It would indeed have been clearer if I had written "some ultimate ends", but at least I didn't write (or mean) "all ultimate ends". Let me admit, though, for what it's worth, that here she scores a point.

In her last half-dozen paragraphs Polanowska-Sygulska finally comes to the nub of our disagreement, "and this is where the story really starts" ${ }^{10}$. Even here she is distracted into unprofitable byways. She observes that "Hardy deplores his not having persuaded Berlin to change his mind". Not at all: I was just as ready to change my mind if Berlin had persuaded me of the validity of his view. I still am, if someone else so persuades me.

She also objects that I have refined my terminology and my arguments since the discussion with Berlin took place, thus weighting the scales unreasonably against him. I plead guilty to the former, but not to the latter. If one is concerned to establish truth, one does not observe a statute of limitations that forbids the posthumous introduction of new considerations. If one party to a discussion dies, he is certainly put at a disadvantage in relation to new lines of enquiry; but the enquiry can and should continue, with all the means at its disposal.

My basic position on the central issue is very simple. Berlin rejects, on pluralist grounds, any claim that one system or constellation of values is uniquely true for all people, at all times, in all places. Since values, ends, needs, desires can and do conflict, often incommensurably, there can in principle be no single rational ordering of them that can be defensibly advocated to, still less imposed on, everyone. Attempts to do one or both of these have been made, are being made, and will always be made, in the spheres of both politics and religion. Berlin himself concentrated on the rejection of political or cultural monism, especially the forms of totalitarianism that became dominant in his lifetime, above all Communism and Fascism. My contention is that any religion that claims to be wholly and uniquely true for everyone in all circumstances falls foul of the same objection, and must accordingly be rejected. This puts paid to the principal world religions - certainly

\footnotetext{
I. Berlin, Affirming..., p. 581.

10 Several characters in: S. Milligan, E. Sykes, The Goon Show, "Dishonoured", s. 5, ep. 12, first broadcast: 14.12.1954, script available at: http://bit.ly/2mQzb6t, accessed on: 29.09.2019.
} 
Christianity and Islam - even if there are grey areas where we find forms of spirituality that do not make universal claims. About Buddhism, Confucianism, Hinduism, Judaism and Shintoism, for example, it is perhaps not possible to be so unambiguously clear. But in my submission it is part of the core essence of religious belief as such that universalist claims are made. The point of religion includes the delivery of certain truth to believers. Polanowska-Sygulska summarises this case well: "if pluralism is to be taken seriously, then mainstream religions have to be rejected".

What does Polanowska-Sygulska say against this position of mine? I select the points that seem clearest from a sometimes foggy discussion.

8. I confuse universalism with monism. No: in the case of religion, both terms describe the same thing. A religion that is universally true is also monistically true: it is true for everyone (universalism), and it is the only truth (monism) - because it necessarily excludes all rivals.

9. I confuse religious monism with external monism. No again: in the case of religion, both terms once more describe the same thing. Religious monism is "the view that there is only one true religion, which is therefore universal" ${ }^{11}$; external monism is the denial of external pluralism ("a pluralistic attitude to rival universalisms"12) - that is, it is exemplified by the view, again, that there is only one true religion, which is therefore universal.

10. I ignore, in the case I make against religious pluralism, my own account of what Polanowska-Sygulska calls "the double nature of religions, that is, that they operate to a certain extent like scientific theories, but to some degree they are like cultures or even myths". In their "scientific" aspect they can hardly be plural, but in their cultural or mythical aspect they can co-exist with other religions. True enough, but the existence of the (monistic) "scientific" aspect, which for me includes allegedly definitive moral injunctions, is enough by itself to exclude religious pluralism. Polanowska-Sygulska refers favourably to Leszek Kołakowski's recommendation of inconsistency, but that strikes me as a cop-out, an excuse for lazy thought. Consistency where consistency is due. If the best defence of religion against a charge of inconsistency that Polanowska-Sygulska can mount is a defence of inconsistency, religion is in trouble.

11. Michael Jinkins, Giambattista Vico and Johann Gottfried Herder (persons of varying degrees of celebrity) are both pluralists and Christians. But the errors of others do not justify our making the same errors. As Polanowska-Sygulska observes, "Hardy would probably say that they were mistaken". Quite.

I return to my starting point. Polanowska-Sygulska and I have different temperaments and/or personal histories. We therefore start from different prejudices when we consider the status of religious belief. Both of us should try to stand outside our prejudices when evaluating each other's arguments. I have tried to do this here, but may not have succeeded. Nevertheless, I hope I have given the reader some objective grounds to doubt the truth of Polanowska-Sygulska's position (to which, I maintain, she clings in the teeth of the evidence), and to think my own worth considering.

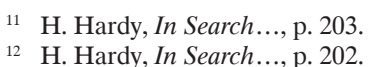




\section{BIBLIOGRAFIA / REFERENCES:}

Berlin, I. (2002). Liberty. Oxford: Oxford University Press.

Berlin, I. (2015). Affirming: Letters 1975-1997. London: Random House UK.

James, W. (1907). Pragmatism: A New Name for Some Old Ways of Thinking. London-New YorkBombay-Calcutta: Longmans, Green and Co.

Hardy, H. (2018). In Search of Isaiah Berlin: A Literary Adventure. London: I.B. Tauris. 